\title{
Hubungan Tingkat Pengetahuan Ibu Tentang Diare Dengan Kejadian Diare Akut pada Balita di Kelurahan Lubuk Buaya Wilayah Kerja Puskesmas Lubuk Buaya Padang Tahun 2013
}

\author{
Silvia Rane ${ }^{1}$, Yusri Dianne Jurnalis ${ }^{2}$, Djusmaini Ismail ${ }^{3}$
}

\begin{abstract}
Abstrak
Pengetahuan ibu mengenai diare merupakan salah satu faktor yang mempengaruhi terjadinya diare akut seperti ketidaktahuan ibu akan penyebab diare, bagaimana cara penularan diare, dan cara pencegahan diare. Hal ini menyebabkan angka kejadian diare akut menjadi tinggi. Tujuan penelitian ini adalah menentukan hubungan antara tingkat pengetahuan ibu tentang diare dengan kejadian diare akut pada balita di Kelurahan Lubuk Buaya. Metode penelitian adalah analitik dan pengolahan data menggunakan uji chi-square. Penelitian dilakukan di Puskesmas Lubuk Buaya Padang dari bulan Juli hingga bulan Agustus 2013. Ada 40 subjek penelitian dengan usia rata-rata responden yaitu 29,93 tahun, tingkat pendidikan terbanyak yaitu lulusan SLTA 18 orang (45\%) dan responden dengan pekerjaan terbanyak adalah ibu rumah tangga 27 orang $(67,5 \%)$. Pengetahuan ibu mengenai diare dengan tingkat pengetahuan sedang 27 orang $(67,5 \%)$, rendah 8 orang $(20 \%)$ dan tinggi sebanyak 5 orang $(12,5 \%)$. Kejadian diare akut pada balita sebanyak 23 orang $(57,5 \%)$ dan yang tidak mengalami diare akut 17 orang (42,5\%). Berdasarkan hasil uji chi-square, tingkat pengetahuan ibu tidak memiliki hubungan dengan kejadian diare akut pada balita dengan $p<0,749$ (nilai $p>0,05$ ). Tidak terdapat hubungan yang bermakna antara tingkat pengetahuan ibu dengan kejadian diare akut pada balita di Kelurahan Lubuk Buaya Padang.
\end{abstract}

Kata kunci: pengetahuan ibu, diare akut, balita

\begin{abstract}
Mother's knowledge about acute diarrhea was one of factors that affecting the occurrence of diarrhea such the lack of mother's knowledge about cause of diarrhea, the transmission and how to prevent diarrhea. This causes incidence of acute diarrhea was high. The objective of this study was to determine the relation between level of mother's knowledge about diarrhea and incidence of acute diarrhea on children under five years old. This study used methode of analitycal cross sectional approach. This study was conducted on 40 mothers who have children younger than five years old. The instrument of this study used questionnaire. The analysis data used chi-square test for data processing. This study was held in Lubuk Buaya village and the questionnaire was taken from July until August 2013. The average of age was 29.93 years old. Most samples were 18 samples graduated from senior high school (45\%), as house wife were 27 samples $(67,5 \%)$. The prevalence mother with moderate level of acute diarrhea knowledge were 27 samples (67,5\%), low level were 8 samples (20\%) and high level were 5 samples (12,5\%). The incidence of acute diarrhea was 23 samples (57,5\%) and with no incidence of acute diarrhea was 17 samples (42,5\%). Based on chi square test, we found the significant score was 0,749 ( $p>0,05)$. The result of this study was mother's knowledge had no significant correlation with incidence of acute diarrhea on children under five years old in Lubuk Buaya village.
\end{abstract}

Keywords: mother's knowledge, acute diarrhea, children under five years

Affiliasi penulis: 1. Prodi Profesi Dokter FK Unand (Fakultas Kedokteran Universitas Andalas Padang), 2.Bagian Gastroenterologi Anak FK Unand/RSUP DR.M.DJamil, 3.Bagian Fisika FK Unand
Korespondensi : Silvia Rane, Email : viaaaokela@yahoo.com Telp: 081277898851 


\section{PENDAHULUAN}

Berdasarkan data WHO, diare membunuh dua juta anak di dunia setiap tahun. Di Indonesia, diare merupakan salah satu penyebab kematian kedua terbesar pada balita dan urutan ketiga bagi bayi serta urutan kelima bagi semua umur. ${ }^{1,2}$

Penyakit diare masih merupakan masalah global dengan derajat kesakitan dan kematian yang tinggi di berbagai negara terutama negara berkembang dan sebagai salah satu penyebab utama tingginya angka kesakitan dan kematian anak di dunia. Secara umum diperkirakan lebih dari 10 juta anak berusia dibawah 5 tahun di dunia meninggal setiap tahun, $20 \%$ diantaranya meninggal karena infeksi diare. $^{3}$

Ada penderita diare sebanyak 12720 orang pada tahun 2012 di Kota Padang. Dinas Kesehatan Kota Padang mencatat bahwa angka kejadian diare di Kelurahan Lubuk Buaya pada tahun 2012 mencapai 493 kasus, Air Dingin 374 kasus, Kuranji 334 kasus, Bungus 364 kasus, Padang Pasir 318 kasus. Angka kejadian di Lubuk Buaya ini merupakan angka terbesar dibandingkan dengan angka kejadian diare di kelurahan lainnya di kota Padang. ${ }^{4}$

Faktor yang mempengaruhi terjadinya diare diantaranya adalah pengetahuan orang tua, personal hygiene yang kurang, lingkungan yang tidak bersih, keadaan sosial ekonomi dan perilaku masyarakat. Pengetahuan orang tua merupakan salah satu penyebab terjadinya diare karena ketidaktahuan orang tua akan penyebab diare, bagaimana cara penularan diare dan cara pencegahan diare sehingga angka kejadiaan diare menjadi tinggi. ${ }^{5}$

Berdasarkan latar belakang diatas, maka perlu diteliti tentang hubungan tingkat pengetahuan ibu tentang diare dengan kejadian diare akut pada balita di Kelurahan Lubuk Buaya Wilayah Kerja Puskesmas Lubuk Buaya Padang.

\section{METODE}

Penelitian ini bersifat analitik untuk melihat hubungan suatu variabel dengan variabel lainnya dengan mengidentifikasi variabel yang ada. Desain cross sectional pada studi ini yaitu penelitan dengan variabel yang diteliti sekaligus dalam waktu sama. ${ }^{6}$
Penelitian ini dilaksanakan di Kelurahan Lubuk Buaya wilayah kerja Puskesmas Lubuk Buaya Padang pada tanggal 21 November 2012 - 30 Agustus 2013.

Populasi target dari penelitian ini adalah ibu yang memiliki balita. Populasi terjangkau dari penelitian ini adalah ibu yang mempunyai balita di Kelurahan Lubuk Buaya. Sampel adalah sebagian dari populasi yang memenuhi kriteria inklusi yaitu ibu yang mempunyai balita umur 0-5 tahun di Kelurahan Lubuk Buaya dan ibu yang bersedia menjadi responden dan mampu untuk menyelesaikan rangkaian pengambilan data.

Pengambilan sampel dilakukan secara acak sederhana (simple random sampling) yaitu bahwa setiap anggota atau unit populasi mempunyai kesempatan yang sama untuk diseleksi sebagai sampel, dengan cara mengundi anggota populasi atau teknik undian.

Tingkat pengetahuan ibu tentang diare pada balita dinilai melalui 20 pertanyaan di dalam kuesioner mengenai definisi, etiologi, patofisiologi, medikasi, pencegahan diare serta manajemen gejala termasuk meminimalisasi faktor penyebab. Hasil skor didapatkan dari skor persentase jawaban yang benar.

Pada penelitian ini tingkat pengetahuan ibu tentang diare dikategorikan menjadi tiga kategori :

a. Tinggi bila jawaban benar $76-100 \%$

b. Sedang bila jawaban benar $60-75 \%$

c. Rendah bila jawaban benar $<60 \%$

Kejadian diare akut pada balita dinilai melalui kuesioner berupa 1 pertanyaan wawancara yaitu "Apakah balita mengalami diare aku dalam 3 bulan terakhir?" dengan pilihan jawab ya dan tidak.

Pada penelitian kejadian diare akut pada balita dikategorikan menjadi 2 kategori :

a.Ya :Jika balita mengalami diare akut dalam 3 bulan terakhir.

b.Tidak :Jika balita tidak mengalami diareakut dalam 3 bulan terakhir

Lembar kuesioner terdiri dari lembar kuesioner data dasar, lembar kuesioner tingkat pengetahuan ibu, dan kejadian diare akut pada balita. Lembar kuesioner data dasar berisi tentang karakteristik subjek penelitian yaitu usia, tingkat pendidikan dan pekerjaan. 
Penandatanganan informed consent dan wawancara untuk pengisian kuesioner dilakukan pada ibu yang memenuhi kriteria inklusi dan namanya ditetapkan melalui undian.

Data yang terkumpul dari penelitian ini akan dicatat dan diolah lebih lanjut untuk dilakukan uji statistik secara komputerisasi. Analisis yang dilakukan secara univariat dan bivariat. Analisis univariat akan menyajikan data dalam bentuk tabel distribusi frekuensi sehingga terlihat gambaran deskriptif dari variabel yang diteliti. Analisis bivariat dilakukan dengan uji kemaknaan chi-squre untuk melihat hubungan antara dua variabel yaitu variabel bebas dan terikat.

Hasil

\section{Karakteristik Responden}

Data subjek penelitian sebanyak 40 orang.

Tabel 1. Sebaran responden berdasarkan usia

\begin{tabular}{cccccc} 
& Rerata & SD & Med & Min & Mak \\
\hline Usia & 29,93 & 4,906 & 30,00 & 20 & 44 \\
\hline
\end{tabular}

Tabel 1 di atas menunjukkan usia rata-rata responden yaitu 29,93 tahun.

Tabel 2. Distribusi frekuensi responden berdasarkan pendidikan

\begin{tabular}{lcc}
\hline Pendidikan & $\mathbf{n}$ & $\mathbf{\%}$ \\
\hline SD & 1 & 2,5 \\
SMP & 8 & 20 \\
SLTA & 18 & 45 \\
Diploma & 6 & 15 \\
S1 & 7 & 17,5 \\
\hline
\end{tabular}

Tabel 2 di atas menunjukkan tingkat pendidikan terbanyak yaitu lulusan SLTA 18 orang (45\%).

Tabel 3. Distribusi frekuensi responden berdasarkan pekerjaan

\begin{tabular}{lcr}
\hline Pekerjaan & $\mathbf{n}$ & $\%$ \\
\hline lbu Rumah Tangga & 27 & 67,5 \\
PNS & 3 & 7,5 \\
Wiraswasta & 10 & 25 \\
\hline
\end{tabular}

Tabel 3 menunjukkan pekerjaan responden terbanyak yaitu ibu rumah tangga 27 orang $(67,5 \%)$.

Tabel 4. Distribusi frekuensi tingkat pengetahuan ibu mengenai diare

\begin{tabular}{lcr}
\hline $\begin{array}{l}\text { Tingkat } \\
\text { Pengetahuan }\end{array}$ & $\mathbf{n}$ & \% \\
\hline Rendah & 8 & 20 \\
Sedang & 27 & 67,5 \\
Tinggi & 5 & 12,5 \\
\hline
\end{tabular}

Berdasarkan Tabel 4 di atas tingkat pengetahuan ibu mengenai diare dengan tingkat pengetahuan sedang 27 orang $(67,5 \%)$, rendah 8 orang $(20 \%)$ dan dengan tinggi sebanyak 5 orang $(12,5 \%)$.

Tabel 5. Distribusi frekuensi kejadian diare akut pada balita

\begin{tabular}{lcc}
\hline Kejadian Diare Akut & $\mathbf{n}$ & $\%$ \\
\hline Tidak & 23 & 57,5 \\
Ya & 17 & 42,5 \\
\hline
\end{tabular}

Berdasarkan Tabel 5 di atas didapatkan kejadian diare pada balita sebanyak 23 orang $(57,5 \%)$ dan yang tidak mengalami diare akut 17 orang (42,5\%).

\section{Hubungan Tingkat Pengetahuan Ibu tentang Diare} dengan Kejadian Diare Akut pada Balita

Tabel 6. Hasil analisis hubungan tingkat pengetahuan ibu tentang diare dengan kejadian diare akut pada balita

\begin{tabular}{|c|c|c|c|c|c|}
\hline \multirow{3}{*}{$\begin{array}{c}\text { Tingkat } \\
\text { Pengetahuan Ibu }\end{array}$} & \multicolumn{4}{|c|}{ Kejadian Diare Akut } & \multirow{3}{*}{$\mathbf{P}$} \\
\hline & \multicolumn{2}{|c|}{ Tidak } & \multicolumn{2}{|c|}{ Ya } & \\
\hline & $\mathbf{n}$ & $\%$ & $n$ & $\%$ & \\
\hline Rendah & 5 & 62,5 & 3 & 37,5 & \multirow{2}{*}{0,749} \\
\hline Sedang\& Tinggi & 18 & 56,3 & 14 & 48,8 & \\
\hline
\end{tabular}

Dari tabel diatas diketahui ibu dengan tingkat pengetahuan mengenai penyakit diare rendah sebanyak 5 orang $(62,5 \%)$ dengan balita yang tidak 
mengalami kejadian diare akut dan 3 orang $(37,5 \%)$ dengan balita yang mengalami diare akut. Ibu dengan tingkat pengetahuan sedang dan tinggi didapatkan 18 balita yang tidak mengalami kejadian diare akut dan $14(48,8 \%)$ balita yang mengalami kejadian diare akut.

Dalam penelitian ini didapatkan nilai signifikansinya sebesar 0,749 , nilai $p>0,05$ maka dapat disimpulkan tidak terdapat hubungan yang bermakna antara tingkat pengetahuan ibu mengenai penyakit diare dengan kejadian diare akut pada balita.

\section{PEMBAHASAN}

Responden dalam penelitian ini adalah ibu-ibu yang mempunyai balita di Kelurahan Lubuk Buaya Wilayah Kerja Puskesmas Lubuk Buaya Padang. Gambaran umum usia rata-rata responden yang menjadi subjek penelitian yaitu 29,93 tahun, responden penelitian berdasarkan pendidikan, didapatkan tingkat pendidikan terbanyak yaitu lulusan SLTA 18 orang $(45 \%)$ dan berdasarkan pekerjaan responden didapatkan 27 orang $(67,5 \%)$ responden dengan pekerjaan terbanyak adalah ibu rumah tangga.

Pada ibu yang mempunyai balita, dari hasil kuisioner didapatkan bahwa pengetahuan tentang diare sedang dengan persentase $(67,5 \%)$.

Menurut analisis peneliti, pengetahuan ibu yang sedang disebabkan karena rata-rata ibu berpendidikan SMA sebanyak 18 orang (45\%), sebagian besar ibuibu berusia diatas 30 tahun, usia terendah 20 tahun dan usia tertinggi 44 tahun. Orang yang usianya matang dan berpendidikan tinggi wawasannya lebih luas dibandingkan yang berpendidikan rendah termasuk wawasan tentang diare.

Ada juga ibu-ibu yang berpengetahuan rendah tentang diare, pengetahuan ibu yang rendah dapat juga dilihat dari hasil pengisian kuisioner yang telah dibagikan kepada ibu. Dari pengetahuan ibu yang rendah sebagian ibu menyatakan tidak tahu bagaimana cara pencegahan diare berulang, cara penggunaan air bersih, dan tidak tau bagaimana perawatan alat-alat bailta seperti mencuci botol balita sebelum diberikan ke balita. Ada juga beberapa ibu berpengetahuan rendah meskipun berasal dari pendidikan tinggi dan pekerjaannya PNS atau wirawasta. Menurut peneliti bisa saja dikarenakan ibu yang sibuk bekerja sehingga jarang datang ke puskesmas atau posyandu untuk mendengarkan sosialisai tentang diare.

Beberapa ibu memiliki pengetahuan tinggi meskipun tergolong dalam ibu rumah tangga dan berpendidikan rendah atau sedang, menurut peneliti hal ini dikarenakan ibu rumah tangga yang tidak bekerja diluar rumah sehingga waktunya penuh untuk merawat balita, rajin datang ke Puskesmas, rajin datang ke Posyandu dan ada waktu untuk segera datang ke PKM terdekat ketika balita terkena diare, sehingga diare pada balita dapat teratasi dengan cepat.

Kejadian diare pada balita subjek penelitian sebanyak 23 orang $(57,5 \%)$ yang tidak mengalami diare akut dan 17 orang (42,5\%) yang mengalami kejadian diare akut. Ini artinya angka kejadian diare di Kelurahan Lubuk Buaya masih cukup tinggi.

Ibu dengan tingkat pengetahuan mengenai penyakit diare yang rendah, hanya 5 orang $(62,5 \%)$ yang balitanya tidak mengalami kejadian diare akut dan 3 orang $(37,5 \%)$ dengan balita yang mengalami diare akut. Ibu dengan tingkat pengetahuan sedang dan tinggi yang balitanya tidak mengalami kejadian diare akut sebanyak 18 orang $(56,3 \%)$ dan 14 orang $(48,8 \%)$ dengan balita yang mengalami kejadian diare akut.

Dalam penelitian ini didapatkan nilai significancy-nya sebesar 0,749 , nilai $p>0,05$ maka dapat disimpulkan tidak terdapat hubungan yang bermakna antara tingkat pengetahuan ibu mengenai penyakit diare dengan kejadian diare akut pada balita.

Menurut peneliti, didapatkan beberapa ibu balita yang berpengetahuan tinggi tentang diare namun balita masih mengalami diare pada 3 bulan terakhir, hal ini bisa saja karena ibu balita yang bekerja seharian sehingga balita di urus oleh pengasuh yang pengetahuannya rendah tentang diare, atau bisa juga karena ibu balita yang mengetahui banyak tentang diare namun tidak diaplikasikan kepada kehidupan sehari-hari dalam merawat balita.

Yance (2009) membuktikan melalui penelitian yang mendapatkan ada hubungan yang bermakna antara lingkungan, social ekonomi dan pengetahuan 
ibu dengan kejadian diare akut pada balita. ${ }^{7}$

Namun Wahyuni (2006) juga mendapatkan hasil yang sama yaitu tidak terdapat hubungan yang bermakna antara pengetahuan ibu dengan kejadian diare pada balita. ${ }^{8}$

\section{SIMPULAN}

Tidak terdapat hubungan yang bermakna antara tingkat pengetahuan ibu tentang diare dengan terjadinya diare pada balita.

\section{DAFTAR PUSTAKA}

1. World Health Organization. Diarrhoeal disease (serial online) 2013 April (diunduh 7 Juli 2013). Tersedia dari: URL: HYPERLINK http://www.who. int/mediacentre/factsheets/fs330/en/

2. Walker CL. Fisher, Robert EB, Rotavirus vaccine and diarrhea mortality: quantifying regional variation in effect size. BMC Public Health. 2011;11(3):516.
3. Agtini, Destri M. Morbiditas dan mortalitas diare pada balita di Indonesia tahun 2000-2007. Buletin Jendela Data dan Informasi Kesehatan. 2011; 2: $1-44$.

4. Dinas Kesehatan Kota Padang, Profil kesehatan Sumbar. Padang: Dinas Kesehatan Kota Padang; 2012.

5. Irwanto. IImu Penyakit anak diagnosis dan penatalaksanaan. Jakarta: Salemba Medika; 2000.

6. Sastroasmoro S, Ismael S. Dasar-Dasar Metodologi Penelitian Klinis. 2002. Edisi ke-2. Jakarta: CV.Sagung Seto; 2002

7. Yance. Hubungan sosial ekonomi, pengetahuan ibu dan lingkungan dengan kejadian diare pada balita. (skripsi). Pekanbaru: Program Studi Pendidikan Dokter Universitas Riau; 2009.

8. Wahyunl D. Hubungan tingkat pengetahuan dan sikap ibu dengan kejadian diare (skripsi). Bengkulu: Program Studi Keperawatan Poltekes; 2006 